\title{
Financial Tips on the Need to Identify Active Degassing Structures When Planning Territory Development Using the Functional Zoning Method
}

\author{
Arina Vyacheslavovna Rudenko ${ }^{1} \&$ Valeriia Valerevna Shaimardanova ${ }^{1}$ \\ ${ }^{1}$ Department of Geography and Cartography Institute of Management, Economics and Finance, Kazan Federal \\ University, Kazan, Russia \\ Correspondence: Arina Vyacheslavovna Rudenko, Department of Geography and Cartography Institute of \\ Management, Economics and Finance, Kazan Federal University, Kazan, Russia. E-mail: aroud@ list.ru
}

Received: September 2, 2020

Accepted: October 20, 2020

Online Published: December 24, 2020

doi:10.5430/ijfr.v12n1p71

URL: https://doi.org/10.5430/ijfr.v12n1p71

\begin{abstract}
The article demonstrates financial instructions and ring degassing structures decoded by the author's technique in the northeast and southeast of Kazan. The structures of various types were identified in areas of the territories of the Volga and Soviet districts of the city and mapped on the functional zones of Kazan of these areas. Residential areas Nagorny, Aki, Quarry of the Sovetsky district, and Mirny, Ferma-2 of the Volga district of Kazan were selected as the research territories. This matter overly helps visually identify areas of the city that are in potential jeopardy of non-human impact. The article indicates the hypothesis about the need to consider the active structures of hydrogen degassing during the development of the territory from analyzing the functional zoning scheme of the studied territory, and provides a detailed comparative analysis of the distribution of ring structures in residential and green functional zones.
\end{abstract}

Keywords: hydrogen degassing, karst, suffosion, functional zoning, residential zone, residential areas

\section{Introduction}

The active development of the urban territory of Kazan over the past few years has led to a substantial increase in urban housing development in the peripheral parts. However, often planning for the development of specific territories does not include analysis of existing active traces of hydrogen degassing, which is accompanied by the formation of karst landforms in these places. Ignoring these construction conditions leads not only to immediate technical difficulties but also to an increase in the risk of collapse during the subsequent operation of buildings. This aspect was considered by the authors of this article from the hypothesis about the need to take into account the distribution sites of active degassing structures when planning residential development. The indicated hypothesis is realized by comparing the existing scheme of functional zoning of the studied regions with places of manifestations of active degassing structures for a part of the Volga and Soviet districts of Kazan.

\section{Methods}

In the analysis, visual decoding methods of active degassing structures were used, as well as comparative analysis and comparison methods.

In (Rudenko, 2019), methods for monitoring the traces of hydrogen degassing manifested on the Earth's surface by terminal structures of various types, in particular karst funnels, dips, suffusion, subsidence and uplifts with overgrowing hydrophilic vegetation or swamping, flooding, and flooding (Larin et al., 2015; Shestopalov \& Makarenko, 2013), (Shestopalov \& Bublyas, 2016), (Shestopalov et al., 2001) and others.

\section{Results and Discussion}

Using the technique mentioned above, the presence and development of annular structures of hydrogen degassing in the territory of Kazan were monitored according to observations and measurements, by the detection and description of annular structures of the karst-suffusion type, as well as data from flooding and subsidence (Zharkova et al., 2007), (Akhiyarova et al., 2008 \& Latypov et al., 2017), (Mirzoev et al., 2006 \& Shevelev et al., 2014).

Thus, it is noted that the areas of subsidence soil development are potentially flooded (5.6\% of the city territory), which significantly increases the risk of subsidence phenomena that often occur in the city of Kazan (Zharkova et al., 2017). This article presents a map of the prevalence of the city of Kazan with various types of flooding processes. In particular, 
hazardous karst areas, areas of subsidence, and wetland development have been identified.

Currently, on the territory of the villages of Aki, Nagorny, Derbyshki, Karyer and Tsaritsyno, located in the north-eastern part of the city of Kazan, the processes of formation of karst-suffusion dips, funnels, lows, etc.

Both karst and karst-suffusion processes take place on the territory, characterized by several karst depressions and dips (usually very old), hundreds of karst-suffusion funnels and saucer-shaped depressions (generally relatively younger) (Latypov et al., 2017).

Route inspection of sites with coordinate reference, measuring geometric parameters and establishing the approximate time of dips, a laboratory study of the composition, structure and properties of karst rocks showed that a significant number of modern karst dips were recorded within the Knox-Kinderka interfluve, south of the village. Quarry, to a lesser extent - south of the village. Nagorny, north of the Quarry ravine, as well as in the vicinity of the village of Aki, on the right bank of the river Kinderka.

In the north-east of Kazan, karst and karst-suffosion processes, which often manifest themselves as dips of small diameter and depth, are in the foreground.

The diameter of the failed funnels varies from 2 to $10 \mathrm{~m}$, averaging $5 \mathrm{~m}$, the depth varies from 1.5 to $3.0 \mathrm{~m}$, on average 2.0-2.5 m. In some cases, closely located funnels are combined, and funnels located close to the edges of the ravines, grow into daughter gullies or stimulate the development of landslides. At the eastern tip of Aki, the surface karst relief forms look like linear furrows, with a width of $0.5 \mathrm{~m}$ to $3 \mathrm{~m}$. The size of the karst damage for this territory is $2 \%$, that is, 1026 funnels per $1 \mathrm{~km} 2$. In one year, approximately 30 failures form here. The affected area is characterized by high karst hazard (Akhiyarova et al., 2008).

On the Tsaritsyno site, the maximum density of karst-suffusion forms for the urban area is $1024 \mathrm{pcs} / \mathrm{km} 2$, up to ten fresh dips are formed annually (Latypov et al., 2017).

The map of zoning and occurrence depths of karst rocks and the surface manifestation of karst processes of the territory of the Republic of Tatarstan according to structural drilling and field studies at a scale of 1: 500000 reflects the roof zones of karst rocks at different depths. According to these data, most of the southeastern territory of Kazan is included in the roofing zone of karst rocks at a depth of $0-50 \mathrm{~m}$ with surface manifestations of karst-suffusion processes.

The roof of karst rocks is most closely traced in the area of the village. Derbyshki (0.5 - $10 \mathrm{~m})$, on the Kremlin hill (9-13 m).

Short-term geodetic measurements (2000-2001) in the city of Kazan show that in the eastern part of Kazan the relief changes noticeably in certain areas within 1-2 years; subsidence and failures are observed (Mirzoev et al., 2006).

According to the above studies, the areas of the villages of Aki, Derbyshka, TsaritsinskyBugor, Karyer and Nagorny are represented by karst-suffusion forms corresponding to the sites of active degassing according to the results of the study. However, direct visual interpretation is difficult and requires the use of other methods.

Large positive ring structures were identified. At the tops, round failed funnels are often traced in the photographs, in some places waterlogging is noticeable.

In the southeast of Kazan, the annular structures of hydrogen degassing are represented by various forms that are well decrypted in satellite imagery.In the Mirny, Boriskovo, SolovinayaRoscha, LesnoyGorodok area, and to the south are widely represented by watered, swamped subsidence structures, as well as heaving mounds, overgrown with forest vegetation, often with the development of a secondary form of degassing and flooding.

All hydrogen degassing structures in these areas are old, but there are also new forms.

In particular, in the course of the study, it was found that the SolovinayaRoscha residential complex and the Fairy Forest residential complex were built in areas of active swamping and subsidence, corresponding in all respects to signs of hydrogen degassing (Figure 1).

At the stage of viewing satellite images from 2004 to 2020. It was found that in 2009, in the place of the described LCs, there were clear traces of subsidence with waterlogging of the territory, which remained visible in all pictures of subsequent years. In 2014, the construction of micro-districts, now already populated, began there.

It is known that today more than $50 \%$ of buildings and structures, including new ones, have lost and are losing their strength as a result of subsidence and through cracks (Shestopalov \& Bublyas, 2016). All the dangers of constructing ring hydrogen degassing structures on the ground were described in more detail in (Rudenko, 2019). 


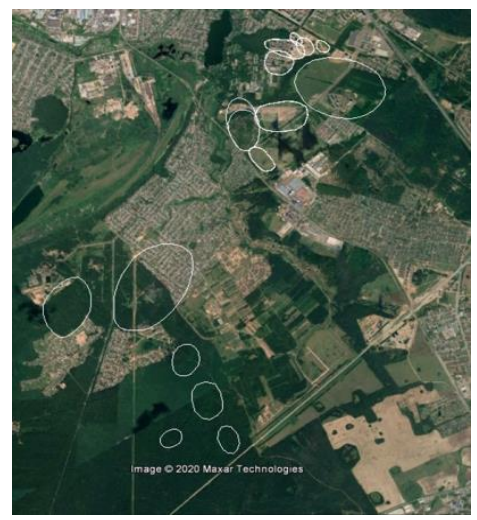

Figure 1. Ring structures of positive and negative type with watering and swamping in the Mirny-Boriskovo are and ZhKSolovininayaRoscha and Fairy Forest

The most visual comparison of the city territory with active ring structures is reflected through the superposition of the data of the selected objects on the scheme of the existing functional zoning of the city. In the context of this article, the distribution of functional zones in areas with a large number of active hydrogen degassing structures was analyzed - in the Volga and Soviet districts of the city.

Modern functional zoning reflects the anthropogenic pressure on urban landscapes, i.e., combination of natural and technical systems, location of pollution sources, urban population density. In aggregate, the economic development of the urban territory is expressed through various zones (residential, industrial, etc.) and has a clear spatial expression (Ivashkina\& Kochurov, 2019). Zoning of the territory is designed to provide a favorable living environment, as well as protection against the effects of emergencies of untouched nature. When comparing the author's scheme of functional zoning with a map of the active distribution of hydrogen degassing, cartographic material was obtained, which shows the existing functional zones in the city and active ring structures (Figure 2, Figure 3).

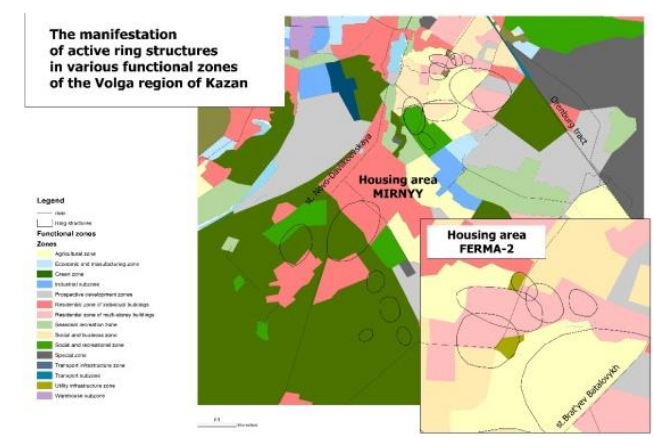

Figure 2. Comparison of functional zones with active ring structures of the Volga district of Kazan

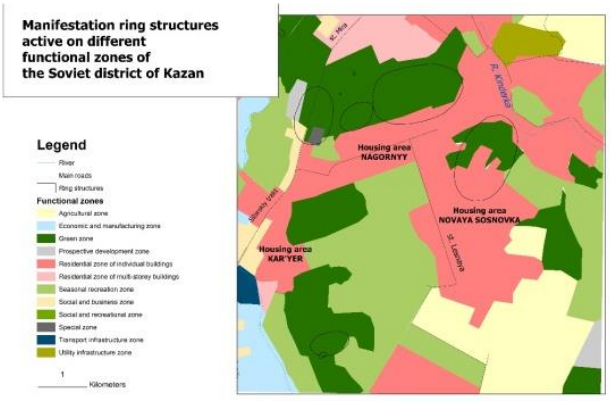

Figure 3. Comparison of functional zones with active ring structures of the Soviet district of Kazan 
This comparative analysis showed the coincidence of some active structures of hydrogen degassing with the residential zone. At the same time, ring structures are located both in the territory of individual construction villages and in new large multi-story residential complexes. These phenomena are especially noticeable in the Volga district, in the residential areas of Mirny and Ferma-2. Southeast of the Ferma-2 micro-district, in the area of Batalov Brothers Street, active construction of new residential complexes, such as the LesnoyGorodok residential complex, is currently underway. Several houses have already been built. In the Farm-2 area, ring structures also affect communal infrastructure facilities, in particular, a large parking complex is located on this site.

In the Sovetsky district, the location of active forms is confined mainly to the green zone - these are large forested areas that are not used well, used both for certain types of recreation and for harvesting. Birch Grove is located north of the Nagorny residential area, where several ring structures are found. Southeast of Nagorny, in the area of the Aki housing estate, these ring structures also affect the residential zone of individual development.

\section{Summary}

The growth of the urban area of Kazan in the last couple of years has resulted in a significant rise in urban accommodation development in the peripheral parts.

The placement of residential areas in active degassing structures gives rise to hazards of performing business. These risks include flooding the territory in the zone of ring structures, increased probability of deformation of the foundations of buildings due to subsidence, elevations, flooding, or the appearance of failed funnels, destruction of the buildings themselves to properties of hydrogen embrittle metal structures. On the territory of non-residential areas, ring degassing structures are hazardous for road and railroad tracks and pipelines (Zharkova et al., 2007). Given this, we note the need to apply methods for monitoring the active structures of hydrogen degassing in the general planning and creation of functional zoning schemes, specifically.

\section{Conclusion}

A comparison of the map of hydrogen degassing structures with the developed scheme of functional zoning of the Volga and Sovetsky districts of Kazan confirmed the hypothesis that there were no such surveys in the planning of construction. In our opinion, this position creates risks for the development of specific areas of the city, both new, only developed areas and existing housing estates. Such surveys and studies of the functional zoning of the city, in conjunction with geological processes, will help to avoid these risks and smooth out the risks of construction.

\section{Acknowledgments}

The work is performed according to the Russian Government Program of Competitive Growth of Kazan Federal University.

\section{References}

Akhiyarova, Y. R., Zaynullin, A. R., \& Nabiullina, M. I. (2008). Patterns of formation of karst-suffusion processes within the Prikazansky district. In The collection: Sergeevsky readings. International Year of Planet Earth: Problems of Geoecology, Engineering Geology and Hydrogeology Materials of the annual session. Scientific Council of the Russian Academy of Sciences on the problems of geoecology, engineering geology and hydrogeology.

Ivashkina, I. V., \& Kochurov, B. I. (2019). Urboecodiagnostics and balanced development of Moscow. M.: Infra-M, Additional materials. Retrieved from https://new.znanium.com/

Larin, N., Zgonnik, V., Rodina, S., Deville, E., Prinzhofer, A., \& Larin, V. N. (2015). Natural molecular hydrogen seepage associated with surficial, rounded depressions on the European craton in Russia. Natural Resources Research, 24(3), 369-383.

Latypov, A. I., Zharkova, N. I., Nuriev, I. S., Khuzin, I. A., \& Yabbarova, E. N. (2017). Patterns of formation of karst-suffusion processes in the north-east of Kazan. In The collection: Prospects for the development of engineering surveys in construction in the Russian Federation Materials of reports of the XIII All-Russian Conference of Survey Organizations.

Mirzoyev, K. M., Stepanov, V. P., Gatiyatullin, N. S., Tarasov, E. A., Gatiyatullin, R. N., Kashurkin, P. I., \& Kozhevnikov, V. A. (2006). Deep karst and modern movements of the Earth's surface in Tatarstan. Georesursy, 18(1), 44-47.

Rudenko, A. V. (2019). The method of a direct interpretation of the ring structures of hydrogen degassing in the territories where people live and housekeeping according to GoogleMaps and Google Earth. Geopolitics and 
Ecogeodynamics of the Regions.

Shestopalov, V. M., \& Bublyas, V. N. (2016). On the formation of low-channel-channel migration structures. Geological Journal.

Shestopalov, V. M., \& Makarenko, A. N. (2014). Some results of studies developing the VI Vernadsky's idea about "gas breathing" of the Earth. Deep processes of degassing of the bowels of the Earth. Geologichnyy Zhurnal, (3), 348.

Shestopalov, V. M., Lyalko, V. I., Sitnikov, A. B., et al.. (2001). Water exchange in hydrogeological structures of Ukraine. Water exchange in hydrogeological structures and the Chernobyl disaster. In V. M. Shestopalov (Ed.), Kiev: Institute of Geol. Sciences of NAS of Ukraine; Scientific Ing. Hydrogeoecol Center.

Shevelev, A. I., Zharkova, N. I., Bubnov, Yu. P., Latypov, A. I., Khuzin, I. A., \& Galleev, R. K. (2014). Monitoring the geological environment of the city of Kazan.

Zharkova, N. I., Khuzin, I. A., Shevelev, A. I., \& Galleev, R. K. (2007). Technological processes of flooding within the territory of the city of Kazan. Uchenyezapiski KSU, 149.

\section{Copyrights}

Copyright for this article is retained by the author(s), with first publication rights granted to the journal.

This is an open-access article distributed under the terms and conditions of the Creative Commons Attribution license (http://creativecommons.org/licenses/by/4.0/). 